UDC $378.4(437.6)$

\title{
Academic mobility in Slovakia: incoming and outgoing student migration flows
}

\author{
Klyuchkovych T.*
}

Uzhhorod National University, Uzhhorod, Ukraine

\section{Received: 27.08.2021 Accepted: 24.09.2021}

\begin{abstract}
In the article modern situation of academic mobility of students in the Slovak Republic under the conditions of educational internationalization is analyzed. The main conditions and tools of implementing academic mobility in Slovakia are clarified. Academic mobility for all participants of educational process under modern conditions is an important part of higher education internalization. It is defined that implementation of development strategy of international mobility is one of the priority tasks for the national policy in the Slovak Republic. Academic mobility finds systematic support at the Slovak state level. Appropriate conditions have been created for the implementation of academic mobility at the institutional, national and European levels. Along with the benefits, internationalization and mobility poce new challenges for Slovak society. This article looks at three aspects of student mobility flows: incoming mobility, outgoing mobility and mobility balance. There is a problem of imbalance between incoming and outgoing forms of mobility in Slovakia. It is empirically established that Slovakia belongs to the countries with strong flows of initial degree mobility. In the context of Slovakia's European integration, there has been an increase in the number of students participating in academic mobility programs. Factors that stimulate the initial academic mobility of Slovak students are the attractive image of foreign universities, the quality of education and educational services, better employment opportunities, various scholarship programs, lower tuition costs, social support for students and others. Factors such as proximity, language, historical ties, geographical distance, bilateral relationships and political framework conditions are key determinants in selecting a country in which to study. Despite the obvious benefits of international mobility, researchers are increasingly focusing on the problem of "brain drain" and the loss of intellectual potential. Slovakia's problem is that students do not return to their home country after completing their studies abroad. Academic mobility has become one of the channels of migration in Slovakia. In the long term, the potential of the educated and highly qualified population is weakening. This can negatively affect the development of society in economic, cultural, scientific and social aspects. Based on the analysis of the current state of mobility in Slovakia, it is concluded that the country's higher education system is characterized by a significant degree of internationalization.
\end{abstract}

Key words: Slovakia, higher education, foreign students, educational migration, incoming mobility, outgoing mobility.

\section{Академічна мобільність у Словаччині: вхідні та вихідні потоки міграції студентів}

\author{
Ключкович Т. В. \\ Ужгородський національний університет, Ужгород, Україна
}

\begin{abstract}
Анотація. У статті проаналізовано сучасну ситуацію з академічною мобільністю студентів у Словацькій Республіці в умовах освітньої інтернаціоналізації. З'ясовано основні умови та інструменти реалізації академічної мобільності в Словаччині. Академічна мобільність для всіх учасників освітнього процесу в сучасних умовах є важливою складовою інтернаціоналізації вищої освіти. Визначено, що реалізація стратегії розвитку міжнародної мобільності $є$ одним із пріоритетних завдань національної політики у Словацькій Республіці. Академічна мобільність знаходить системну підтримку на рівні державної політики Словаччини. Для реалізації академічної мобільності створені відповідні умови на інституційному, національному та загальноєвропейському рівнях. Поряд з перевагами, інтернаціоналізація та мобільність формують нові виклики перед словацьким суспільством. У цій статті розглядаються три аспекти потоків студентської
\end{abstract}

Corresponding Author: Klyuchkovych Tetyana. Tel. (0312)640314. E-mail: tetyana.klyuchkovych@uzhnu.edu.ua Uzhhorod National University,

University Str., 14, Uzhhorod, Transcarpathian region, Ukraine, 88000.

Відnовідальний автор: Ключкович Тетяна Василівна. Тел. (0312)640314. E-mail: tetyana.klyuchkovych@uzhnu.edu.ua вул. Університетська 14, м. Ужгород, Закарпатська обл., Україна, 88000. 
мобільності: вихідна мобільність, вхідна мобільність і баланс мобільності. В Словаччині існує проблема дисбалансу між вхідною та вихідною формами мобільності. Емпірично встановлено, що Словаччина належить до країн із сильними потоками вихідної ступеневої мобільності. В контексті європейської інтеграції Словаччини відбулося зростання кількості студентів, які беруть участь у програмах академічної мобільності. Чинниками, які стимулюють вихідну академічну мобільність словацьких студентів, є привабливий імідж закордонних університетів, якість навчання та освітніх послуг, кращі можливості працевлаштування, різноманітні стипендіальні програми, нижчий рівень витрат на навчання, соціальна підтримка студентів та ін. Такі фрактори як мова, історичні зв'язки, географічна відстань, двосторонні відносини та політичні рамки $€$ визначальними для студентів при виборі країни для навчання. Попри очевидні переваги міжнародної мобільності, дослідники все частіше наголошують на проблемі «відпливу мізків» і втраті інтелектуального потенціалу. Проблема Словаччини полягає в тому, що студенти не повертаються до рідної країни після завершення навчання за кордоном. Академічна мобільність у Словаччині стала одним із каналів міграції. У довгостроковій перспективі послаблюється потенціал освіченого та висококваліфрікованого населення, що може негативно позначитися на розвитку суспільства в економічному, культурному, науковому та соціальному аспектах. На основі аналізу актуального стану мобільності в Словаччині зроблено висновок, що система вищої освіти країни характеризується значним ступенем інтернаціоналізації.

Ключові слова: Словаччина, вища освіта, іноземні студенти, освітня міграція, вхідна мобільність, вихідна мобільність.

\title{
Академическая мобильность в Словакии: входные и выходные потоки миграции студентов
}

\author{
Ключкович Т. В. \\ Ужгородский национальный университет, Ужгород, Украина
}

\begin{abstract}
Аннотация. В статье проанализирована современная ситуация с академической мобильностью студентов В Словацкой Республике в условиях образовательной интернационализации. Выяснены основные условия и инструменты реализации академической мобильности в Словакии. Академическая мобильность для всех участников образовательного процесса в современных условиях является важной составляющей интернационализации высшего образования. Определено, что реализация стратегии развития международной мобильности является одной из приоритетных задач национальной политики в Словацкой Республике. Академическая мобильность находит системную поддержку на уровне государственной политики Словакии. Для реализации академической мобильности созданы соответствующие условия на институциональном, национальном и общеевропейском уровнях. Наряду с преимуществами, интернационализация и мобильность формируют новые вызовы перед словацким обществом. В этой статье рассматриваются три аспекта потоков студенческой мобильности: выходная мобильность, входная мобильность и баланс мобильности. В Словакии существует проблема дисбаланса между входящей и исходящей формами мобильности. Эмпирически установлено, что Словакия относится к странам с сильными потоками выходной ступенчатой мобильности. В контексте европейской интеграции Словакии произошел рост количества студентов, участвующих в программах академической мобильности. Факторами, которые стимулируют выходную академическую мобильность словацких студентов, являются привлекательный имидж зарубежных университетов, качество обучения и образовательных услуг, лучшие возможности трудоустройства, различные стипендиальные программы, более низкий уровень расходов на обучение, социальная поддержка студентов и др. Такие фракторы как язык, исторические связи, географическое расстояние, двусторонние отношения и политические рамки являются определяющими для студентов при выборе страны для обучения. Несмотря на очевидные преимущества международной мобильности, исследователи все чаще акцентируют внимание на проблеме «утечки мозгов» и потере интеллектуального потенциала. Проблема Словакии заключается в том, что студенты не возвращаются в родную страну после завершения обучения за рубежом. Академическая мобильность в Словакии стала одним из каналов миграции. В долгосрочной перспективе ослабляется потенциал образованного и высококвалифицированного населения, что может негативно сказаться на развитии общества в экономическом, культурном, научном и социальном аспектах. На основе анализа актуального состояния мобильности в Словакии сделан вывод, что система высшего образования страны характеризуется значительной степенью интернационализации.

Ключевые слова: Словакия, высшее образование, иностранные студенты, образовательная миграция, входная мобильность, выходная мобильность.
\end{abstract}




\section{Bcmyn}

В умовах прискорення глобалізаційних процесів інтернаціоналізація є передумовою забезпечення довгострокової конкурентоспроможності національних систем вищої освіти. Однією із важливих складових інтернаціоналізації є академічна мобільність, темпи і масштаби якої істотно зросли за останні десятиліття. Розбудова Європейського простору вищої освіти (далі ЄПВО) наблизила національні системи освіти країн-учасниць до загальноєвропейських стандартів, що зокрема сприяло й академічній мобільності. Адже стратегічним завданням у рамках розбудови ЄПВО є розширення можливостей для мобільності студентів, викладачів і науковців.

Як країна-учасниця ЄПВО Словацька Республіка здійснила ряд перетворень, спрямованих на реалізацію стратегій інтернаціоналізації та подолання бар'єрів на шляху мобільності у ссрері освіти та науки. Завдяки академічній мобільності вдалося посилити освітній і науковий потенціал її учасників, налагодити міжнародні зв'язки, збагатити національну культуру. Дослідники (У. Тайхлер [16, 17], Р. Галл і С. Лукач [7], Г. Ліповска і Я. Фішер [8]) розкривають різноманіття фоорм мобільності та інструментарію їі підтримки, відзначають переваги, які відкрилися перед Словаччиною в контексті реалізації інтернаціоналізаційних заходів. Попри наявність очевидних переваг, ряд вчених (напр. М. Багна [4], А. Нагійова [10]) наголошують на окремих суперечливих аспектах академічної мобільності у Словаччині, пов'язаних 3 якістю освітніх послуг, еміграцією випускників закордон. Вивчення і врахування словацького досвіду може бути корисним для України, для якої сьогодні актуальним є розв'язання ряду проблемних аспектів академічної мобільності.

Meта роботи: з'ясування сучасного стану розвитку міжнародної академічної мобільності у Словаччині в аспекті розкриття умов її реалізації, вхідних і вихідних потоків міграції студентів.

\section{II Матеріал і методи дослідження}

Мобільність студентів вважається одним із ключових вимірів міжнародної якості вищої освіти та простеження тенденцій освітньої інтернаціоналізації [17, с. 96], що обумовлює динамічний науковий інтерес до проблематики, інновативність і комплексність дослідницьких підходів. Для розкриття багатомірності інтернаціоналізації словацької вищої освіти, взаємозв'язків між структурними рівнями, видами та напрямами академічної мобільності в дослідженні використано системний і структурнофункціональний підходи. Зіставлення показників академічної мобільності, встановлення особливостей їі розвитку в загальноєвропейському контексті стало можливим завдяки компаративному методу. Для емпіричної перевірки теоретичних положень були використані міжнародні бази даних щодо мобільності в рамках країн Організації економічного співробітництва та розвитку (далі ОЕСР) та ЄПВО. В даному контексті слід наголосити на необхідності вдосконалення систем збору даних про академічну мобільність (зокрема кредитну), оскільки існує методологічна неузгодженість щодо вимірювання різних форм і застосування критеріїв мобільності, бракує однорідних порівнюваних міжнародних даних та ін. $[18$, c. $155 ; 16$, c.15].

Академічна мобільність постійно залишається важливою темою в основних документах, які приймаються в рамках Болонського процесу. В дослідженні предметом аналізу були положення Льовенського комюніке 2009 р. [5], Римського комюніке 2020 р.[13], Звіту про імплементацію Болонського процесу за 2020 р. [18] та ін. Розуміння «академічної мобільності» змістовно розвивалося у соціальному, організаційному, функціональному аспектах, відображаючи динаміку та інтенсивність процесів в освітньому просторі. Ключові документи Болонського процесу підкреслюють насамперед цільовий та інструментальний зміст мобільності студентів і працівників в контексті реалізації стратегії інтернаціоналізації вищої освіти. Відповідно до актуальної вітчизняної нормативно-правової регламентації академічна мобільність розуміється як «можливість учасників освітнього процесу навчатися, викладати, стажуватися чи проводити наукову діяльність в іншому вищому навчальному закладі (науковій установі)» в країні чи поза її межами [1].

Різні класифікаційні схеми академічної мобільності підкреслюють їі:

- суб'єктність (мобільність студентів, викладачів, персоналу),

- просторовість (національна, регіональна, міжнародна),

- темпоральність (довгострокова, короткострокова) та ін. 
В програмних і аналітичних документах Болонського процесу оперують двома основними видами мобільності - ступенева (з метою здобуття ступеня вищої освіти) і кредитна (з метою здобуття кредитів EKTC).

Також визначені два напрямки (потоки) мобільності - вхідна (застосовується до країни призначення) і вихідна (застосовується до країни походження студента).

Ступенева мобільність є довгостроковим видом міжнародної мобільності, яка включає фрізичний перетин національного кордону з метою вступу до ВНЗ для здобуття ступеня вищої освіти (свідоцтва) в країні призначення. Кредитна мобільність - це короткострокова форма здобуття вищої освіти та/або стажування за кордоном з метою отримання академічних кредитів, що будуть визнані у ВНЗ постійного місця навчання студента [18, с. 133-134].

В умовах інтенсифікації міграційних процесів в освітньо-науковій сфрері посилилося прагнення країн до врівноваження вхідної та вихідної мобільності (т.зв. «баланс мобільності»), що особливо важливо для ступеневої мобільності. Ступенева мобільність здійснює довгостроковий і стійкий вплив як на країни, що приймають студентів, так і на країни, які відряджають студентів. 3 одного боку, академічна мобільність може сприяти нарощуванню інтелектуального потенціалу та міжнародної співпраці, а 3 іншого - привести до «відтоку мізків» [9, с. 2].

\section{III Результати}

Важливою якісною перевагою, яка відкрилася перед Словаччиною в умовах європейської інтеграції, стала інтенсифікація міжнародної співпраці в освітньому просторі. Процес інтернаціоналізації словацької вищої школи посилює залученість країни до програм ЄС у сфрері освіти та науки, що передбачають мобільність студентів, науковців і викладачів у рамках європейського освітнього простору, партнерську участь університетів у спільних проєктах, презентацію їхніх результатів на міжнародному рівні, обмін навчальними програмами та ін. У рамках стратегії інтернаціоналізації вищої освіти, підтримки їі привабливості Словаччина націлена на розвиток академічної мобільності в рамках $€ C$ та відповідну співпрацю між навчальними та науковими інституціями.

Як ключова форма інтернаціоналізації освіти та науки академічна мобільність динамічно змінюється під впливом комплексу умов і чинників. У Словаччині створені умови для академічної мобільності студентів, які зокрема включають:

- адаптацію національної нормативно-регулятивної бази з академічної мобільності до європейських освітніх стандартів;

- створення інформаційних баз даних про програми міжнародної мобільності;

- організаційну та фрінансову підтримку мобільності на рівні державної політики;

- визнання кваліфікацій шляхом використання ЄКТС, додатку до диплома;

- індивідуальне формування навчального плану шляхом вибору навчальних дисциплін, які належать до вибіркових дисциплін у межах ВН3;

- реалізацію навчальних програм іноземними мовами, що розраховані на студентів-іноземців; запровадження інтегрованих програм навчання, одночасного паралельного навчання за різними спеціальностями, програмами спільних/подвійних дипломів;

- можливість переривати та поновлювати навчання в різних університетах та ін.

Академічна мобільність у Словаччині $є$ системним явищем, організованим на рівні державної політики. На сучасному етапі інтернаціоналізація вищої освіти є одним зі ключових напрямків діяльності Міністерства освіти, науки, досліджень та спорту Словацької Республіки (далі МОНДССР), що зафріксовано у довгостроковій стратегії щодо розвитку університетів на 2016-2021рp. [6] і програмній заяві Уряду Словаччини на 2020-2024 рр. [12].

В Словаччині адміністрування програмами з підтримки академічної мобільності здійснюють Словацька академічна асоціація з міжнародного співробітництва, Словацька академічна інформаційна агенція та IUVENTA - Словацький інститут молоді [3, с. 119]. Ці організації відіграють координаційну роль у реалізації програм мобільності як через міжнародне, так і державне фрінансування, надають консультаційні, організаційні та інформаційні послуги студентам, викладачам і науковцям. 
Важливою умовою розвитку академічної мобільності на інституційному рівні $є$ спроможність ВН3 приймати іноземних студентів та відправляти своїх студентів в університети інших країн. У словацьких університетах створені консультаційні відділи, бюро, головними завданнями яких $€$ надання інформації про міжнародну мобільність та допомога студентам, викладачам та адміністративному персоналу в реалізації можливостей навчання чи стажування за кордоном, а також сприяння прийому іноземних студентів.

Для реалізації стратегій інтернаціоналізації та підтримки академічної мобільності в Словаччині запроваджені механізми різного масштабу: світового, загальноєвропейського, регіонального та на рівні двосторонніх угод. Впродовж 1990-х - 2000-х pp. Словаччина поетапно долучалася до загальноєвропейських програм мобільності Erasmus, Socrates, Leonardo da Vinci, Lifelong Learning, Erasmus Mundus, Tempus, Erasmus+.

На сучасному етапі успішним інструментом підтримки мобільності у вищій школі $є$ програма Erasmus+, яка надає можливості для індивідуальної мобільності студентів, викладачів, вчителів, адміністративних працівників, а також стимулює партнерство між університетами, школами, підприємствами та некомерційними організаціями. 3 ресурсів МОНДССР реалізується Національна стипендіальна програма, призначена для підтримки мобільності студентів, викладачів, митців і науковців. Широкі можливості для навчання та стажування надають стипендіальні програми, які $€$ результатом діючих двосторонніх угод, укладених між Словаччиною та іншими державами (словацькоукраїнська, словацько-чеська, словацько-австрійська співпраця та ін.). 32000 р. Словаччина поряд 3 Чехією, Польщею та Угорщиною, активно розбудовують центральноєвропейське наукове та освітнє співробітництво в рамках Міжнародного вишеградського фонду. Словацькі університети залучені до реалізації регіональних програм CEEPUS, які підтримують співпрацю у ссрері вищої освіти країн Центральної Європи.

Отже, академічна мобільність у Словаччині знайшла фінансову та організаційну підтримку через різні інструменти та програми, як національного, так і європейського рівня. Сьогодні словацькі студенти мають широкі можливості подорожувати за кордон, як для здобуття освітніх ступенів, так і для короткострокового навчання, використовуючи різні ресурси. I словаки активно користуються можливостями, що зокрема підтверджують статистичні дані щодо вихідної мобільності.

Станом на 2018 р. близько 2\% студентів ВН3 у країнах ОЕСР були зараховані на навчання за кордоном. За винятком Люксембургу, Словаччина демонструвала найвищу частку студентів, які навчалися за кордоном - 19\% (рис. 1).

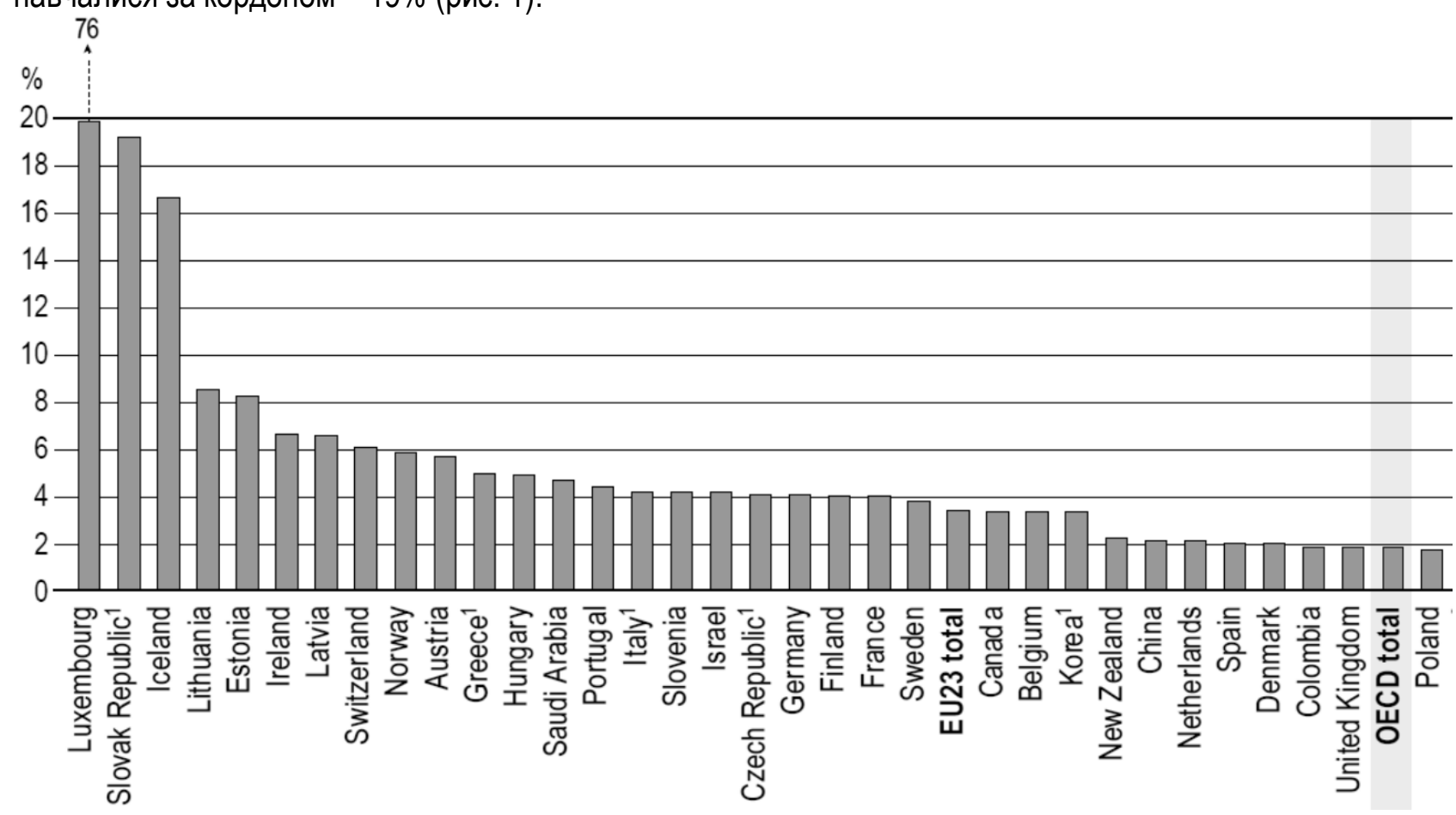

Рис. 1. Частка студентів-іноземців, які навчаються в країнах ОЕСР (станом на 2018 р.) [11, с. 229] 
Якщо у 1999 р. у закордонних ВНЗ навчалося 4483 словаків, то у 2017 р. - 32010 [7, с. 780].

Згідно зі розрахунками коефіцієнту вихідної мобільності в 2016-2017 рp. у рамках ЄПВО, словацькі громадяни активно виїжджали на навчання за кордон і надавали перевагу ступеневій мобільності.

Коефіцієнт вихідної ступеневої мобільності в Словаччині склав 13\%, тоді як середнє значення в $€ П В О-3,5 \%[18$, с. $137-139]$ :

- бакалаврський рівень - 13,6\%,

- магістерський $-11,7 \%$,

- докторський $-14,1 \%$.

Коефіцієнт вихідної кредитної мобільності словацьких студентів склав $3,7 \%$, тоді як середнє значення в ЄПВО $-5,9 \%[18$, с. $137-139]$ :

- бакалаврський $-2,6 \%$,

- магістерський $-4,8 \%$,

- докторський $-4,6 \%$.

Щодо показників кредитної мобільності слід врахувати застереження про відсутність відповідних даних у ряді країн.

Табл. 1. Коефріцієнт вихідної мобільності випускників (ступеневої та кредитної) за країнами походження, 2016-2017рр. (у \%)[18, с.136]

\begin{tabular}{|c|c|c|c|c|c|c|c|c|c|c|c|c|c|c|c|c|c|c|c|c|}
\hline & AD & LU & CY & NL & FI & FR & DE & NO & LV & LT & AT & MT & EL & IT & IS & SK & BA & CH & CZ & PT \\
\hline $\begin{array}{c}\text { Кредитна } \\
\text { мобільність }\end{array}$ & 8,0 & 6,9 & 1,7 & 22,6 & 15,2 & 14,6 & 12,8 & 8,5 & 7,2 & 6,4 & 9,6 & 5,4 & 1,7 & 9,1 & $:$ & 3,7 & $:$ & 8,0 & 8,0 & 7,5 \\
\hline $\begin{array}{c}\text { Ступенева } \\
\text { мобільність }\end{array}$ & 83,0 & 73,6 & 35,2 & 2,3 & 3,8 & 3,4 & 5,1 & 8,5 & 8,5 & 8,6 & 5,0 & 9,0 & 12,1 & 4,5 & 13,5 & 13,0 & 12,5 & 4,1 & 3,9 & 3,6 \\
\hline & $\mathbf{D K}$ & $\mathbf{A Z}$ & $\mathbf{H R}$ & $\mathbf{B E}$ & $\mathbf{E S}$ & $\mathbf{B G}$ & $\mathbf{H U}$ & $\mathbf{R O}$ & $\mathbf{R S}$ & $\mathbf{A L}$ & $\mathbf{S I}$ & $\mathbf{I E}$ & $\mathbf{A M}$ & $\mathbf{U K}$ & $\mathbf{K Z}$ & $\mathbf{U A}$ & $\mathbf{P L}$ & $\mathbf{T R}$ & $\mathbf{6}$ (BBO \\
\hline $\begin{array}{c}\text { Кредитна } \\
\text { мобільність }\end{array}$ & 9,2 & $:$ & 4,5 & 6,2 & 7,7 & 1,4 & 3,8 & 1,8 & 1,4 & $:$ & 2,8 & $:$ & $:$ & 3,3 & $:$ & $:$ & $:$ & $:$ & $\mathbf{5 , 9}$ \\
\hline $\begin{array}{c}\text { Ступенева } \\
\text { мобільність }\end{array}$ & 1,6 & 10,4 & 5,4 & 3,6 & 1,9 & 8,2 & 4,1 & 6,1 & 5,5 & 6,6 & 3,7 & 5,7 & 5,4 & 0,8 & 3,8 & 3,5 & 1,0 & 0,8 & $\mathbf{3 , 5}$ \\
\hline
\end{tabular}

Згідно з представленими даними, в рамках ЄПВО Словаччина належить до країн з сильними потоками вихідної ступеневої мобільності. При чому, на відміну від інших країн ЄПВО, зберігається відносна збалансованість показників вихідної мобільності випускників за 1-м (13,6\%), 2-м (11,8\%) і 3-м $(14,1 \%)$ рівнем вищої освіти [18, с. 137].

Такі фактори як мова, історичні зв'язки, географічна відстань, двосторонні відносини та політичні рамки $є$ визначальними для студентів при виборі країни для навчання [14]. Наприклад, найбільша частка студентів зі Словаччини навчається в Чехії, що $є$ логічним, зважаючи на тісні відносини та взаємні угоди між двома сусідніми країнами, їхнє спільне історичне минуле, культурну та мовну близькість чехів і словаків [2; 8, с. 54]. У 2018 р. 21292 громадян зі словацьким громадянством вступили до тамтешніх університетів і становили 7,4\% від усіх студентів у Чехії. Частка студентів зі Словаччини, які навчаються у чеських університетах, складала 67\% від загальної кількості словаків, що навчаються за кордоном [7, с. 781]. Найпопулярнішими напрямками серед словацьких студентів $є$ природничі та технічні науки, економіка, медицина та фармація [8, с.56]. Популярними для навчання словацьких студентів також є університети Великобританії, Австрії, Німеччини.

3-поміж основних чинників, які мотивують до здобуття вищої освіти за межами Словаччини, студенти найчастіше називають такі: краща репутація закордонних університетів у порівнянні зі 
словацькими ВН3; ширші дослідницькі та творчі можливості; вищі шанси гідного працевлаштування; суперечливий і часто негативний імідж словацьких університетів у медіа; краще соціальне забезпечення студентів; динамічна комунікація і сервіс з боку закордонних ВН3; професіоналізм викладачів та індивідуальний підхід до студентів; практична орієнтованість навчання та ін. [7, с. 781-789; 10, с. 7-10].

Міжнародна мобільність студентів дозволяє отримати нові знання, важливі професійні та соціальні навички, здатність адаптуватися до різних умов і середовищ. Випускники сприяють розширенню наукових, освітніх, культурних контактів зі своїми країнами. Роботодавці цінують професійні, комунікативні, інтеркультурні компетентності випускників зі закордонною освітою. Загалом міжнародна освіта має позитивний вплив як на країни, які приймають іноземних студентів, так і на країни, що відряджають студентів.

Іншою виглядає у Словаччині ситуація з вхідною мобільністю студентів. На рис. 2 наведені дані щодо вхідної студентської мобільності в країнах ОЕСР, де в середньому частка іноземних студентів складає близько 6\% від загальної кількості студентів. У Словаччині частка іноземців складає близько $7 \%$ від загальної кількості студентів ВН3, при чому відмінності між здобувачами освітнього рівня бакалавра, магістра та доктора не є настільки значними, як в інших країнах (рис. 2).

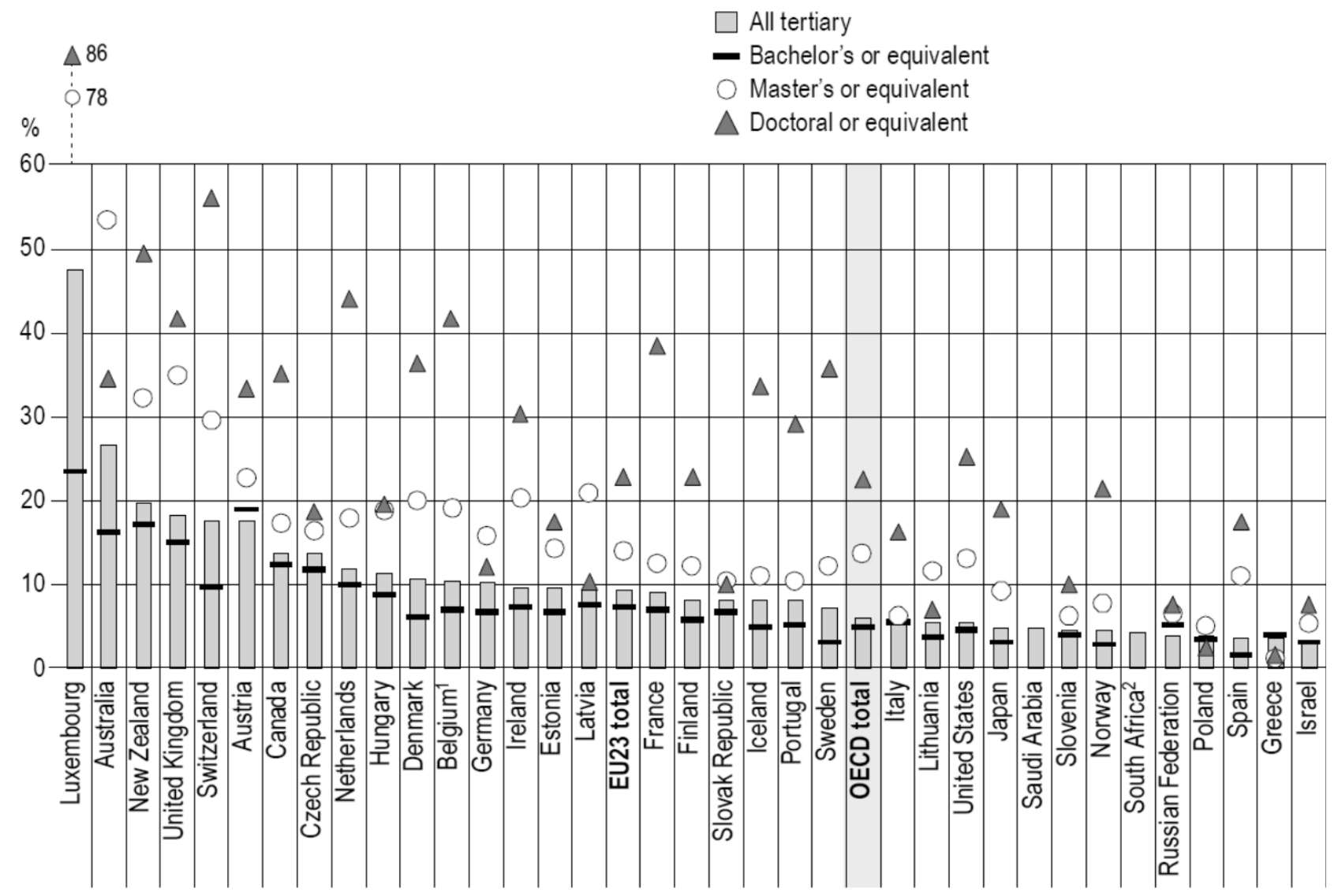

Рис. 2. Вхідна студентська мобільність в окремих країнах ОЕСР за рівнем вищої освіти (станом на 2018 р.) [11, с. 233]

Згідно з розрахунками експертів Групи супроводу Болонського процесу, показник вхідної ступеневої мобільності в Словаччині в 2017 р. склав 6,3 \%, при середньому показнику в 2,6\% у країнах $€ П B \mathrm{:}$

- бакалаврський рівень - 5,2\%,

- магістерський $-7,9 \%$,

- докторський $-8,5 \%$.

Наприклад, в Україні частка студентів зі ступеневою мобільністю склала тільки 0,8\% і є однією 3 найнижчих у рамках ЄПВО (табл. 2). 
Табл. 2. Коефіцієнт вхідної ступеневої мобільності в межах ЄПВО у 2017 р. (у \%) [18, с. 141]

\begin{tabular}{|c|c|c|c|c|c|c|c|c|c|c|c|c|c|c|c|c|c|c|c|c|}
\hline & LU & AD & AT & CH & CZ & CY & DK & BA & NL & HU & UK & SK & MT & BG & LV & BE & RS & PL & RO & DE \\
\hline $\begin{array}{c}\text { Ступенева } \\
\text { мобільність }\end{array}$ & 38,7 & 37,4 & 15,0 & 13,0 & 11,1 & 9,2 & 8,9 & 7,2 & 6,4 & 6,3 & 6,3 & $\mathbf{6 , 3}$ & 5,1 & 5,1 & 4,6 & 4,4 & 4,1 & 3,4 & 3,4 & 3,2 \\
\hline & MK & HR & FI & AM & EL & IT & IS & LT & FR & IE & AZ & NO & ES & PT & AL & UA & TR & KZ & $\mathbf{E n B O}$ \\
\hline $\begin{array}{c}\text { Ступенева } \\
\text { мобільність }\end{array}$ & 3,0 & 2,7 & 2,6 & 2,5 & 2,4 & 2,4 & 4,2 & 2,4 & 2,3 & 2,2 & 1,5 & 1,5 & 1,3 & 1,2 & 1,1 & 0,8 & 0,5 & 0,3 & $\mathbf{2 , 6}$ \\
\hline
\end{tabular}

В порівняльному аспекті частка студентів, які прибули на навчання в Словаччину з інших країн $€ П В О$, засвідчує визначений інтерес здобувачів до словацької вищої освіти, але не є достатньою для забезпечення «балансу мобільності».

Станом на 31.10.2020 р. у Словаччині функціонувало 33 ВН3 (20 громадських, 10 приватних і 3 державних), в яких здобували вищу освіту 1-го і 2-го рівня 130739 студентів [15]. На освітніх програмах 1-го і 2-го рівня навчалося загалом 14615 іноземців: у громадських ВН3 - 11333, приватних - 3028 і державних - 254 студентів. В таблиці 3 наведено кількість іноземних студентів у словацьких ВН3 за окремими країнами походження здобувачів.

Табл. 3. Кількість іноземних студентів на освітніх програмах 1 і 2-го рівня в словацьких ВН3 за окремими країнами (станом на 31.10.2020) [15]

\begin{tabular}{|c|c|c|c|c|}
\hline \multirow{2}{*}{$\begin{array}{c}\text { Країни } \\
\text { походження } \\
\text { студентів }\end{array}$} & Громадські & Приватні & Державні & \multirow{2}{*}{ Разом } \\
\cline { 2 - 4 } & 4720 & 67 & 14 & 4801 \\
\hline Україна & 534 & 2468 & 90 & 3092 \\
\hline Чехія & 491 & 302 & 7 & 800 \\
\hline Сербія & 664 & 46 & 3 & 713 \\
\hline Угорщина & 615 & 1 & 65 & 681 \\
\hline Німеччина & 531 & 12 & 7 & 550 \\
\hline Росія & 519 & 2 & 3 & 524 \\
\hline Норвегія & & & & \\
\hline
\end{tabular}

В аспекті регіону походження в'їзних студентів у Словаччині - то це переважно європейці. Щонайменше 8 з 10 студентів-іноземців прибувають до Словаччини з інших європейських країн [11, с. 231]. Як засвідчують статистичні дані, найбільше іноземних студентів приїжджають з України - 4801 $(32,8 \%)$ і Чехії - 3092 (21,1\%). Іноземці обирають для навчання у Словаччині переважно громадські університети. Окрім якісної європейської освіти, важливою перевагою здобуття освіти в словацьких університетах $€$ доступність для іноземців навчання за кошти словацького бюджету, що приваблює зокрема українську молодь.

Поряд з перевагами, інтернаціоналізація та мобільність формують нові виклики перед словацьким суспільством. Існує необхідність модернізації словацької вищої освіти, посилення ії привабливості, насамперед покращення якості навчання та надання освітніх послуг у тих сферах, де зафіксовані найслабші результати в міжнародному порівнянні.

Академічна мобільність стала не тільки індикатором, але й інструментом вдосконалення освітньої системи. У Словаччині розроблені ряд програм і стратегій, спрямованих на підвищення привабливості університетського навчання для міжнародної мобільності. Вони включають, наприклад, рекламні заходи 
словацьких ВНЗ за кордоном, розширення спектру освітніх послуг і доступності вищої освіти для іноземців, вдосконалення системи оцінювання діяльності викладачів і наукових працівників, розробку стратегій інтернаціоналізації та академічної мобільності на рівні ВН3, підтримку спільних міжнародних проєктів і розробок у рамках двостороннього співробітництва.

Глобальне поширення пандемії коронавірусу серйозно вплинуло на мобільність та інтернаціоналізацію вищої освіти в країнах ЄПВО і Словаччині зокрема, оскільки університети обмежили доступ до приміщень, а країни закрили свої кордони відповідно до карантинних заходів урядів. Криза вплинула на правовий статус іноземних студентів, безперервність навчання, доступ до навчальних матеріалів та ін., що може мати негативні наслідки для міжнародної мобільності у найближчі роки [11, c. 231]. Разом з тим, і світова освітня спільнота намагається адаптуватися до нових умов. В Римському комюніке 2020 р. проголошено важливість розвитку інноваційних міжнародних середовищ у закладах освіти та здобуття досвіду академічної мобільності, використовуючи як фізичний, так і віртуальний або змішаний формати $[13$, с. 6]. У країнах $Є П В О$, і зокрема Словаччині, $€$ вже чимало успішних прикладів створення спільних цифрових освітніх просторів університетами для забезпечення віртуальної мобільності за навчальними курсами та дослідницькими проєктами. Міжнародна академічна мобільність у глобальних умовах вимагає інноваційних підходів до поєднання різних форм навчання, комунікації та активності студентів.

\section{IV Обговорення}

Проблема академічної мобільності є предметом обговорень і дискусій як у Словаччині, так і на рівні ЄПВО. Важливість мобільності студентів, дослідників та адміністрації університетів неодноразово підкреслювалася у ключових програмних документах у ході розгортання Болонського процесу, зокрема на ії значенні для особистісного, інституційного та європейського освітнього розвитку особливо акцентовано в Льовенському комюніке в 2009 р. [5, с. 4]. У Комюніке окреслено амбітну ціль, щоб до 2020 р. принаймні 20\% випускників університетів у межах ЄПВО мали досвід навчання чи професійного стажування за кордоном. Попри те, що переважна більшість країн ЄПВО не досягли встановленого рівня у 2020 р., все-таки вони сконцентрували свої зусилля на стимулюванні міжнародної мобільності. Важливість досягнення раніше визначеної мети мобільності в 20\%, попри поширення пандемії, підтверджено на конфреренції міністрів освіти країн ЄПВО в Римі у 2020 р. [13, с. 6].

Питання стимулювання чи гальмування мобільності та інтернаціоналізації часто підіймаються в дискусіях на національному та міжнародному рівнях. Іноді висловлюються побоювання, що громадяни країни потенційно будуть субсидіювати витрати на освіту іноземних громадян, або ВНЗ будуть залучати «будь-яких» іноземних студентів, замість пошуку «кращих талантів» [18, с. 126].

Однозначності в оцінці потоків вхідної та вихідної мобільності немає. Як правило, вхідна мобільність студентів $€$ визнанням привабливості вищої освіти країни з точки зору надання освітніх послуг, якості навчання чи фінансової підтримки; в той час, як вихідна мобільність може бути результатом заохочення студентів пройти хоча б частину навчання, або здійснення наукових досліджень за кордоном, або результатом низької якості освіти в рідній країні, чи труднощів, з якими стикаються випускники на ринку праці на батьківщині [2, с. 51].

Проблема Словаччини полягає в тому, що відтік студентів за кордон не обмежується лише навчанням, оскільки значна частина з них не планує повертатися. Попри очевидні переваги міжнародної мобільності, дослідники все частіше наголошують на проблемі «відпливу мізків» та втраті інтелектуального потенціалу. Адже одним з ризикових чинників $є$ те, що студенти залишаться за кордоном і після закінчення навчання. За даними різних досліджень, більш ніж половина словацьких студентів не повертається в країну після завершення навчання $[4$, с. $11 ; 7$, с. 790; 8, с. 54]. Також слід взяти до уваги, що поряд з постійно зростаючою часткою словацьких студентів за кордоном, зростає і частка словаків із вищою освітою, які працюють за межами батьківщини.

Відтік словацьких студентів за кордон не компенсується вступом до університетів Словаччини більшої кількості іноземних студентів. У 2018 р. у словацьких університетах навчалися 12706 іноземців, що приблизно на 20 тис. менше, ніж студентів зі Словаччини за кордоном [7, с. 781]. Наразі немає точних даних, скільки з іноземців після завершення навчання залишилися у Словаччині, але очевидною $€$ потреба корекції державної політики в цьому напрямку. Згідно з даними «Індексу інтеграційної 
політики щодо мігрантів» Словаччина не належить до тих країн, які створюють максимально сприятливі умови для навчання, працевлаштування та самореалізації іноземців [19].

Отже, очевидною $€$ проблема дисбалансу між вхідною та вихідною фрормами мобільності (насамперед ступеневої). У даному контексті лунає чимало критичних оцінок щодо якості системи вищої освіти в Словаччині [10, с. 11]. Словаччина, як країна-донор іноземних студентів, у перспективі може отримувати менше вигод від міжнародної освіти випускників, і навіть більше, країна може втрачати свій інтелектуальний потенціал, що, своєю чергою, сповільнюватиме інноваційний розвиток, затримуватиме зростання національної економіки. Ця ситуація $є$ дещо подібною до українських освітніх міграційних реалій. В даному аспекті важливим $є$ аналіз причин і наслідків відтоку молоді за кордон і, можливо, коригування державної, інституційної політики щодо освітнього розвитку та міграції.

\section{V Висновки}

На основі аналізу актуального стану мобільності в Словаччині можна зробити висновок, що система вищої освіти країни характеризується значним ступенем інтернаціоналізації. Процес інтернаціоналізації словацької освіти посилює залученість країни до програм ЄС у сфері освіти та науки, що передбачають мобільність словацьких студентів і викладачів у рамках європейського освітнього простору, партнерську участь ВНЗ у спільних освітніх і наукових проєктах, презентацію їхніх результатів на міжнародному рівні та ін. Академічна мобільність та інтернаціоналізація вищої освіти знаходять системну підтримку на рівні державної політики Словаччини. Академічна мобільність $є$ важливою частиною загальної стратегії інтернаціоналізації словацької вищої освіти і для її реалізації створені відповідні умови на інституційному, національному та загальноєвропейському рівнях.

В контексті європейської інтеграції Словаччини відбулося зростання кількості студентів, які $є$ учасниками академічної мобільності. Чинниками, які стимулюють вихідну мобільність словацьких студентів, є привабливий імідж закордонних університетів, якість навчання та освітніх послуг, кращі можливості працевлаштування, різноманітні стипендіальні програми, нижчий рівень витрат на навчання, соціальна підтримка студентів та ін. Академічна мобільність у Словаччині має асиметричний характер, оскільки за кількісними показниками вихідна мобільність суттєво переважає над вхідною. I в рамках ОРСД, і в рамках ЄПВО Словаччина належить до країн із сильними потоками вихідної ступеневої мобільності, які не врівноважуються потоками вхідної мобільності студентів.

Ще однією проблемою в даному аспекті $є$ неповернення словацьких студентів до рідної країни після завершення навчання за кордоном. Академічна мобільність у Словаччині стала одним із каналів міграції. За сучасних тенденцій освітньої міграції академічна мобільність фоормує нові виклики для словацького суспільства. Адже в довгостроковій перспективі послаблюється потенціал освіченого та висококваліфікованого населення, що може негативно позначитися на розвитку суспільства в економічному, культурному, науковому та соціальному аспектах. 3 огляду на ці ризики актуальним $\epsilon$ підвищення ефективності системи національної академічної мобільності відповідно до зазначених тенденцій освітнього розвитку.

\section{Бібліографрічні посилання}

1. Закон України «Про вищу освіту» від 01.07.2014 р. Відомості Верховної Ради. 2014. № 37-38. C. 2004. URL: https://zakon.rada.gov.ua/laws/show/1556-18\#Text (дата звернення 02.08.2021).

2. Інтернаціоналізація вищої освіти в Україні: методичні рекомендації / За ред. І. Степаненко. К.: ІВО НАПН України, 2016. 158 c.

3. К Кючкович Т. В. Інтеграція системи вищої педагогічної освіти Словацької Республіки у європейський освітній простір: дис. ... канд. пед. наук: 13.00.01; Дрогобиц. держ. пед. ун-т ім. Івана Франка. Дрогобич, 2017. 267 с.

4. Bahna M. Slovenskí absolventi vysokoškolského štúdia v zahraniči: Únik mozgov, alebo otvárajúce sa mobilitné kanály na Slovensku? [Slovak graduates: Brain drain or opening mobility channels in Slovakia]. Working Papers in Sociology. 2015/1. S. 1-13. URL: http://www.sociologia.sav.sk/cms/uploaded/2179_attach_bahna_brain_drain_PT12015b.pdf (дата звернення 02.08.2021).

5. Communique of the Conference of European Ministers Responsible for Higher Education, Leuven and Louvain-la-Neuve. 2829 April 2009. URL: http://www.ehea.info/Upload/document/ministerial_declarations/ Leuven_Louvain_la_Neuve_ Communique_April_2009_595061.pdf (дата звернення 02.08.2021). 
6. Dlhodobý zámer vo vzdelávacej, výskumnej, vývojovej a d’alšej tvorivej činnosti pre oblast' vysokých škôl na roky 2016 -2021. Ministerstvo školstva, vedy, výskumu a športu Slovenskej republiky. Č́́slo uznesenia: 507/2016. URL: https://rokovania.gov.sk/RVL/Resolution/16097/2 (дата звернення 02.08.2021).

7. Hall R., Drál' P., Fridrichová P., Lukáč S. Analýza zistení o stave školstva na Slovensku: To dá rozum. Bratislava: MESA10, 2019. $1127 \mathrm{~s}$.

8. Lipovská H., Fischer J. Brain Drain - Brain Gain: Slovak Students at Czech Universities. Journal in Efficiency and Responsibility in Education and Science. 2015. Vol. 8. No. 3. P. 54-59. https://doi.org/10.7160/eriesj.2015.080301 (дата звернення 02.08.2021).

9. Mobility for better learning. Mobility strategy 2020 for the European Higher Education Area (EHEA). Bucharest, 2012. URL: http://www.ehea.info/media.ehea.info/file/2012_Bucharest/39/2/2012_EHEA_Mobility_Strategy_606392.pdf (дата звернення 02.08.2021).

10. Nagyová A. Mobility vysokoškolských študentov v kontexte skvalitňovania vzdelávacieho systému vysokého školstva. Národný projekt "Vysoké školy ako motory rozvoja vedomostnej spoločnosti“. 13 s. URL: https://vysokoskolacidopraxe.cvtisr.sk/files/nagyova_mobility.pdf (дата звернення 02.08.2021).

11. OECD. Education at a Glance 2020: OECD Indicators. Paris: OECD Publishing. 473 p.

12. Programové vyhlásenie vlády Slovenskej republiky na obdobie rokov 2020-2024. URL: https://rokovania.gov.sk/RVL/Material/24756/1 (дата звернення 02.08.2021).

13. Rome Ministerial Communue. 19 November 2020. URL: http://www.ehea.info/Upload/Rome_Ministerial_Communique.pdf (дата звернення 02.08.2021).

14. Silles M., Abbott A. Determinants of International Student Migration. The World Economy. 2016. Vol. 39. Issue 5. P. 621635. http://dx.doi.org/10.1111/twec.12319

15. Centrum vedecko-technických informácií SR. URL: https://www.cvtisr.sk/ (дата звернення 02.08.2021).

16. Teichler U. Academic Mobility and Migration: What We Know and What We Do Not Know. European Review. 2015. Vol. 23. No. S1. P. 6-37. https://doi.org/10.1017/S1062798714000787

17. Teichler U. Internationalisation of Higher Education: European Experiences. Asia Pacific Education Review. 2009. Vol. 10 (1). P. 93-106. https://doi.org/10.1007/s12564-009-9002-7

18. The European Higher Education Area in 2020: Bologna Process Implementation Report. Luxembourg: Publications Office of the European Union, 2020. 201 p.

19. The Migrant Integration Policy Index. URL: https://www.mipex.eu/slovakia (дата звернення 02.08.2021).

\section{References}

1. Zakon Ukrainy «Pro vyshchu osvitu» vid 01.07.2014 r. Vidomosti Verkhovnoi Rady, 2014, 37-38, 2004. URL: https://zakon.rada.gov.ua/laws/show/1556-18\#Text (acceded 02.08.2021). [in Ukrainian].

2. Internatsionalizatsiia vyshchoi osvity v Ukraini: metodychni rekomendatsii / Za red. I. Stepanenko. K.: IVO NAPN Ukrainy, 2016, 158. [in Ukrainian].

3. Klyuchkovych, T.V. (2017). Intehratsiia systemy vyshchoi pedahohichnoi osvity Slovatskoi Respubliky u yevropeiskyi osvitnii prostir: dys. ... kand. ped. nauk: 13.00.01; Drohobyts. derzh. ped. un-t im. Ivana Franka. Drohobych, 267. [in Ukrainian].

4. Bahna, M. (2015). Slovenskí absolventi vysokoškolského štúdia v zahraničí: Únik mozgov, alebo otvárajúce sa mobilitné kanály na Slovensku? [Slovak graduates: Brain drain or opening mobility channels in Slovakia]. Working Papers in Sociology, 1, 1-13. URL: http://www.sociologia.sav.sk/cms/uploaded/2179_attach_bahna_brain_drain_PT12015b.pdf (acceded 02.08.2021). [in Slovak].

5. Communiqué of the Conference of European Ministers Responsible for Higher Education, Leuven and Louvain-la-Neuve. 2829 April 2009. URL: http://www.ehea.info/Upload/document/ ministerial_declarations/Leuven_Louvain_la_ Neuve_Communique_April_2009_595061.pdf (acceded 02.08.2021).

6. Dlhodobý zámer vo vzdelávacej, výskumnej, vývojovej a d'alšej tvorivej činnosti pre oblast' vysokých škôl na roky 2016 -2021. Ministerstvo školstva, vedy, výskumu a športu Slovenskej republiky. Číslo uznesenia: 507/2016. URL: https://rokovania.gov.sk/RVL/Resolution/16097/2 (acceded 02.08.2021). [in Slovak].

7. Hall, R., Drál', P., Fridrichová, P., Lukáč, S. (2019). Analýza zistení o stave školstva na Slovensku: To dá rozum. Bratislava: MESA10, 1127. [in Slovak].

8. Lipovská, H., Fischer, J. (2015). Brain Drain - Brain Gain: Slovak Students at Czech Universities. Journal in Efficiency and Responsibility in Education and Science, 8 (3), 54-59. https://doi.org/10.7160/eriesj.2015.080301.

9. Mobility for better learning. Mobility strategy 2020 for the European Higher Education Area (EHEA). 2012. Bucharest, 2012. URL: http://www.ehea.info/media.ehea.info/file/2012_Bucharest/39/2/2012_EHEA_Mobility_Strategy_606392.pdf (acceded 02.08.2021).

10. Nagyová, A. Mobility vysokoškolských študentov v kontexte skvalitňovania vzdelávacieho systému vysokého školstva. Národný projekt "Vysoké školy ako motory rozvoja vedomostnej spoločnosti“, $13 . \quad$ URL: https://vysokoskolacidopraxe.cvtisr.sk/files/nagyova_mobility.pdf (acceded 02.08.2021). [in Slovak].

11. OECD. Education at a Glance 2020: OECD Indicators. Paris: OECD Publishing, 473.

12. Programové vyhlásenie vlády Slovenskej republiky na obdobie rokov 2020-2024. URL: https://rokovania.gov.sk/RVL/Material/24756/1 (acceded 02.08.2021). [in Slovak].

13. Rome Ministerial Communue. 19 November 2020. URL: http://www.ehea.info/Upload/Rome_Ministerial_Communique.pdf (acceded 02.08.2021). 
14. Silles, M., Abbott, A. (2016). Determinants of International Student Migration. The World Economy. 2016, 39(5), 621-635. http://dx.doi.org/10.1111/twec.12319

15. Centrum vedecko-technických informácii SR. URL: https://www.cvtisr.sk/ (acceded 02.08.2021) [in Slovak].

16. Teichler, U. (2015). Academic Mobility and Migration: What We Know and What We Do Not Know. European Review, 23(1), 6-37. https://doi.org/10.1017/S1062798714000787

17. Teichler, U. (2009). Internationalisation of Higher Education: European Experiences. Asia Pacific Education Review, 10(1), 93-106. https://doi.org/10.1007/s12564-009-9002-7

18. The European Higher Education Area in 2020: Bologna Process Implementation Report. Luxembourg: Publications Office of the European Union, 2020, 201.

19. The Migrant Integration Policy Index. URL: https://www.mipex.eu/slovakia (acceded 02.08.2021).

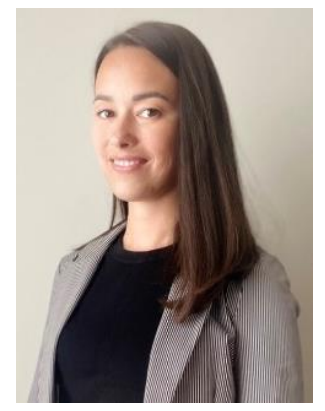

\section{Ключкович Тетяна Василівна.}

Кандидат педагогічних наук,

старший викладач кафедри загальної педагогіки та педагогіки вищої школи,

Ужгородський національний університет,

вул. Університетська 14, м. Ужгород, Закарпатська обл., Україна, 88000.

Тел. (0312)640314. E-mail: tetyana.klyuchkovych@uzhnu.edu.ua

\section{Klyuchkovych Tetyana.}

Candidate of Pedagogical Sciences,

Senior Lecturer at the Department of General Pedagogy and Pedagogy of Higher School,

Uzhhorod National University,

University Str., 14, Uzhhorod, Transcarpathian region, Ukraine, 88000.

Tel. (0312)640314. E-mail: tetyana.klyuchkovych@uzhnu.edu.ua

ORCID: 0000-0003-3702-1086

\section{Citation (APA):}

Klyuchkovych T. (2021). Academic mobility in Slovakia: incoming and outgoing student migration flows. Engineering and Educational Technologies, 9 (3), 18-29. doi: https://doi.org/10.30929/2307-9770.2021.09.03.02

Цитування (ДСТУ 8302:2015):

Ключкович Т. В. Академічна мобільність у Словаччині: вхідні та вихідні потоки міграції студентів / Інженерні та освітні технологіï. 2021. Т. 9. № 3. С. 18-29. doi: https://doi.org/10.30929/2307-9770.2021.09.03.02

Обсяг статmi: $\quad$ сторінок-12; умовних друк. аркушів - 1,738. 